BP WALENTY WOJCIK

Archiwa, Biblioteki

i Muzea Koscielne. T. 36: 1978

\title{
RĘKOPISY BIBLIOTEKI KAPITULNEJ W SANDOMIERZU
}

Biblioteka Kapituły Sandomierskiej posiada stosunkowo niewiele kodeksów rękopiśmiennych. Przedstawiają one jednak wartość dla badań nad historią i kultura, przede wszystkim lokalną. W większości sa to kodeksy pergaminowe, pochodzące $z$ okresu przed upowszechnieniem ksiąg drukowanych. Nie można jednak twierdzić, że zachowane rękopisy średniowieczne stanowiły bibliotekę ówczesnej kapituły. Trzeba raczej przyjąć, że jakaś część ksiąg zaginęla ${ }^{1}$. Zdzierały się także kodeksy częściej używane, np. liturgiczne. Wniosek ten zdaje się potwierdzać fakt, że zachował się tylko jeden mszal z XIV/XV i trzy z XV wieku oraz intonatorium z 1567 i antyfonarz z 1572-1585 r. W calości posiadamy 2 kodeksy z XIII w., 5 - z $\mathrm{XIII} / \mathrm{XIV}, 12-\mathrm{z}$ XIV, $4-\mathrm{z}$ XIV-XV, $14-\mathrm{z} \mathrm{XV}, 2-\mathrm{z}$ XVI, $6-\mathrm{z}$ XVII, 2 - z XVII/XVIII, $9-z$ XVIII, $1-z$ XVIII/XIX i $2-z$ XIX w. Wśród ksiąg starszych, napisanych przed 1600 rokiem, zaliczają się wszystkie poza wymienionymi kodeksami liturgicznymi, 6 kanonicznymi i 1 filologicznym do działu teologii. Przeważa teologia biblijna i spekulatywna. Kazania pojawiają się w XV w. Jako rękopisy nowsze doszły jeszcze pojedyncze kodeksy $z$ historii Kościoła, filozofii, ascetyki, pastoralnej, prawa i gramatyki. Na uwage zasługują wzmianki o lokalnych zwyczajach liturgicznych: „Sic canitur Sandomiriae" - z XIV w., „Intonatorium Ecclesiae Collegiatae Sandomiriensis" - z $1567 \mathrm{r}$.

Napisy i noty proweniencyjne rzucają pewne światło na sposób otrzymywania kodeksów i kształtowania się biblioteki przy kolegiacie. Najczęstsze są wzmianki o kupowaniu książek. W drugiej połowie XIV w. podawano cenę książki: od dwu i pól do 4 marek obiegowych groszy praskich. Zapiska wikariusza kolegiaty sandomierskiej z 1407 r.: "Comparavit ibidem" świadczy, że w Sandomierzu byla wtedy możność kupowania książek. Niektóre napisy pozwalają domyślać się, że ośrodki zakonne - Cystersów, Dominikanów i Franciszkanów brały udział w produkcji i w obrocie książkami. Z porównania chronologii tych notatek nasuwa się domysł, że $z$ biegiem czasu cena książek opadała. Spotykane od końca XIV w. wzmianki: „Manu propria scripsit", ,Scriptum per me..." itp. wskazują, że zaintereso-

1 Z nie znanych przyczyn zaginęly akta oficjalatu sandomierskiego z lat 13981517. P. Bober: Najstarsze ksiegi oficjalatu sandomierskiego, „Pol. sacra”, r. 4: 1951, s. $155-157$. 
wani jakimś dziełem sami przepisywali sobie tekst książki. Czasowniki: „,dedit", „donavit” mówią o przekazaniu kodeksu ze skutkiem za życia właściciela, ,legavit” - ze skutkiem dopiero po jego śmierci. Charakterystyczne są wzmianki z XIV w. o oddaniu księgi przez wicedziekana wikariuszy kolegiackich ,vicariis Ecclesiae Sandomiriensis". Pod r. 1424 wspomina notatka: „Datus ad librarium vicariorum Ecclesiae Sandomiriensis". Jako odbiorca darowanej książki występuje też w XIII/XIV w. „Ecclesia Collegiata". Na podstawie tych i tym podobnych zdan można by wnioskować, że kanonicy posiadali własne książki. Przekazywali je początkowo ogólnie kościołowi kolegiackiemu, a później ze szczególnym przeznaczeniem - do biblioteki kolegium wikariuszy. Wybudowanie ok. 1360 r. nowej świątyni kolegiackiej na miejsce zniszczonej w r. 1259/1260 przez Tatarów pozwolilo ustabilizować i uintensywnić pracę kolegiaty. Zachowane książki teologiczne wskazują na działalność szkoły kolegiackiej. Kanonistyczne związane były ponadto z działalnością archidiakona i oficjała okręgowego. Kaznodziejskie - z duszpasterstwem.

Gdy wzrosła możność nabywania ksiąg drukowanych i księgozbiory kościelne zaczęly szybko powiększać się, władze duchowne zwróciły uwagę na biblioteki. Synod prowincjalny z $1589 \mathrm{r}$. polecil, aby przy katedrach ustanowić spośród kanoników bibliotekarzy i corocznie restaurować księgozbiory ,propter sacerdotes et scholasticos" 2. Od r. 1594 biskupi krakowscy wizytujący kolegiatę $\mathrm{w}$ Sandomierzu powtarzali nakaz przeprowadzenia rewizji zasobów biblioteki i sporządzenia katalogu książek. O ile można się zorientować z informacji źródłowych, rewizje biblioteki kapituły sandomierskiej zaczęly się dopiero w początkach XVIII w. ${ }^{3}$. Wtedy to archidiakon Stefan Żuchowski ofiarował regały biblioteczne, większą ilość książek i polecil sporządzić katalog ${ }^{4}$. Wydano regulamin korzystania ze zbiorów. Zatwierdził go biskup krakowski, wizytujący kapitułę 17 IV 1717. Według katalogu z 1712 r. istniała ,,antiqua bibliotheca". W osobnym dziale spisano jej zawartość: 43 kodeksy pergaminowe i 137 ksiąg z papieru. Były w tym $i$ druki. Z pozycji „Autores [!] in pergameno in folio magno" zachowało się $32^{5}$. Sredniowiecznych rękopisów papierowych - zaledwie $5^{6}$. Resztę

2 Decretales Summorum Pontificum pro Regno Poloniae et constitutiones synodorum, t. III, Poznań 1883, s. 73.

${ }^{3}$ W. Wójcik: Archiwum i Biblioteka Kaptuły w Sandomierzu, ,Arch. Bibl. Muz.", t. 7: 1963, s. $34-35$.

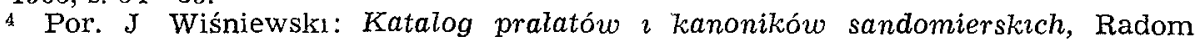
1928 , s. 331-333. Na karcie tytułowej katalogu z 1712 r. zaznaczono: ,cura et opera Archıdiaconi". Zuchowski, dr obojga prawa, byl archidiakonem, oficjałem ì proboszczem w Sandomierzu.

5 Brak natomiast dziel: Brixiensis - Super iure canonico, Discordantium canonum concordia, Compendium theologiae vertatis, Dictionarium; Isıdorus - De origine rerum, Statuta summa super $6^{m}$ Decretalium; Monaldi - Summa canonistica, Manipulus per alphabetum ex SS. Patribus collectus; Nestorii - Sermones; Speculum Saxonicum. Doszły zaś będące zapewne wtedy w użyciu księg1 liturgiczne. Nie objęła ich rewızja biblioteki w 1707 r. Znalazły się one poza katalogıem. Jakąś część z nich uwzględnił późniejszy katalog ks. Andrzeja Wyrzykowskiego.

G Zachowaly się 3 katalogı: 1) Recentior Bibliotheca Collegiatae Sandomirıensis fundationıs [...] Franciscı Stefanı Zuchowsk1 protonotarii apostolici, utrıusque iurıs. doctorıs, archidiaconı et parochı Sandomiriensis anno. D. 1712, kart 177, $31 \times 20 \mathrm{~cm}$, papier, opr. skóra czerwona, wspl., brulion 1 czystopis; 2) Cathalogus lib́rorum iuxta decisionem totius generalis congressus [...] canonicorum conscriptus et in recentiorem cum suls annotationibus ordinem a. 1729 per Joannem Franciscum Kalisz canonicum 
ksiąg ułożono według kryterium językowego ${ }^{7}$. Zdaje się, że po ustawieniu nowych regałów ulożono tam książki według przedmiotów teologicznych. Po tym dopiero sporządził w 1729 r. nowy. katalog na polecenie plenarnej sesji kapituły kanonik prokustosz Jan Franciszek Kalisz ${ }^{8}$. Zespół kodeksów średniowiecznych ulokowal on wtedy "supra fores in capitulario" - czyli nad wejściem do sali posiedzeń kapitulnych. Poza tym część złożono „,extra bibliothecam in capitulario veteris bibliothecae". Pomieszano przy tym rękopisy $\mathrm{z}$ drukami. Najcenniejsze pergaminy wyłączono wtedy i złożono w obszernych szufladach stołu posiedzeń kapituły. W katalogu oznaczono je jako dzialy XVII - „Libri vetustissimi supra fores" i XVI — "Autores [!] extra bibliothecam".

Według miejsca położenia spisano zawartość biblioteki w $1853 \mathrm{r} .^{9}$. Nowy "katalog wyróżnil najpierw: „Libri vetusti in capitulario" - 409 pozycji i „Bibliotheca nova in post-capitulario" z układem tradycyjnym według działów teologii $\mathrm{i}$ innych nauk. Podczas ostatniej wojny spisał ks. Andrzej Wyrzykowski ${ }^{10}$ zawartość biblioteki wedlug ukladu książek na półkach. Dal nową numerację ciągłą dla całości zbioru. Pominął jednak kodeksy przeważnie pergaminowe, złożone w szufladach. Pracy swej nie dokończyl. Jego opisy nie odpowiadaja obowiązującym wytycznym katalogowania ${ }^{11}$.

Ponieważ ciasnota miejsca $i$ dopasowanie książek do zabytkowych regałów nie pozwala na jakiś nowy układ całości, a ilość książek jest stosunkowo niewielka, wydawało się najwłaściwsze, aby spisać rękopisy bez nowego porządkowania ich. Najpierw przeto opisane zostaną kodeksy wedkug katalogu Wyrzykowskiego, następnie - zlożone w drugiej sali w szufladach i w końcu - pojedyncze, znajdujące się w układzie treściowym w różnych działach biblioteki ,nowej" ${ }^{12}$. Na początku podana będzie sygnatura według katalogu Wyrzykowskiego, a później w nawiasach sygnatura dawna i inne oznakowania.

\section{Nr 1}

91 (46) Lac. XIV w. (1333-1370). Perg. $47 \times 35 \mathrm{~cm}$. K. 162. Kol. 2. Opr. deski w sk. wspt.

Rabanus Maurus. Liber Machabaeorum et Novum Testamentum.

1) „Incipit epistola in Librum Machabaeorum... Domino excellentissimo et in cultu christianae religıonıs strenuissimo Ludovıco regi Rabanus vilissımus servus dat" $k$. 1 .

procustodem concinnatus, stron zapısanych $140,31 \times 19 \mathrm{~cm}$, opr. skóra brązowa, wspł.; 3) Katalog $z$ drukowanymı łacińskimr nagłówkamı 1 linıamı $z 1853$ r., kart $46,42 \times 26$ $\mathrm{cm}$. w broszurze, według rewıjji dokonanej $10 \mathrm{~V} 1853$ przez K. Skorzyńskıego, sekretarza kapituly.

- Libri bibliothecae patriae seu aucthorum Polonorum, aucthores Germanici, Italic1, spirituales et politici, Gallici, de Iudaels 1 katalog dodatkowy.

8 Wiśniewski, jw., s. 140-142.

9 Zgodność czystopısu z brulionem potwierdził sekretarz kapituly.

10 W. Wójcik: Ks. Andrzej Wyrzykowski (1879-1955), „Arch. Bibl. Muz.", t. 2 z. $1 / 2: 1961$, s. 300 .

11 Można by tu wymienıc: Wskazówki do katalogowania rękopisów w zbiorach bibliotecznych, Kraków 1935 \& Wytyczne opracowanıa rękopisów w bibliotekach polskich, Wroclaw 1955.

12 Dla ulatwıenia poszukıwań otrzymają kodeksy ręlkopiśmienne widoczne wkładki kartonowe z numerem porządkowym wedlug niniejszego katalogu. Przy porządkowaniu druków trzeba będzıe ułożyć razem calość rękopisów wedlug tej numeracji. 
2) „Incipit Mathaeus evangelista". Na marginesie tarcza z orlem w koronie i napisem w otoku:, „Sigillum magnifici Kasimirı Del gratia regis Poloniae” k. 29.

3) „Explicit Mathaeus. Incipit prefatio... in Marcum evangelistam” k. 46.

4) „Explicit Marcus evangelista. Incıpit praefacıo in Lucam evangelistam. Lucas Syrus natione" k. 56. k. $74 \mathrm{v}$.

5) „Explicit Lucas et incipit prologus in Iohannem. Hic est Iohannes evangelista”

6) „Explicit Iohannes evangelista. Incipit proemum vel praefacio beati Jeronımi presbyterı in epistolas beati Pauli apostoli" k. 86 .

7) „Explicit epistola ad Hebraeos, incipit prologus in Acta Apostolorum” k. 125.

8) „Explicit Novum Testamentum. Incipit libellus venerabilis Bedae presbyteri de scematibus" k. $160 \mathrm{v}$.

Pergamin blały gruby. K. 163 i 164 wyrwane. Ozdobne inicjały na k. 1, 15, 28, 45, $56,57,74,75,88,89,94,96,103,107,110,112,114,115,116,118,125,147,149,153 . \mathrm{Na}$ k. 162 napis: „Ex revisione 1707 connotatum”.

Op r a wa: deska w skórze podwójnej, na spodzıe surowa, wierzchnia biała gładka. Okucıa żelazne. Brak jednej tarczy okucia. Nie ma klamer.

Prow en i en c ja: może dar z dworu królewskiego.

$\mathrm{Nr} 2$

95 (106) Łac. XIII/XIV w. Perg. $44 \times 27$ cm. K. 250. Kol. 2. Opr. deski $w$ sk. wspl.

Vitae.Sanctorum.

1) „Cui cum dicerem, quare fugis... Marcellus dictus est quasi arcens malum... De sancto Antonio" k. 1 .

2) „De sancta Catharina” k. 247v.

3) „De sancta Anastasia" k. 250.

Kodeks uszkodzony: $\mathrm{k}$. wyrwane po $5,100,164$ I na końcu ślad wycięcia 10 kart.

Pismo duzymi literami, jakby rysowanymı. Ozdobne inicjały na $\mathrm{k} .1,2,3,11,12$, $17,18,19,22,25,26,27,29,30,32,34,40,41,45,53,76,89,91,94,98,101,111,119$, $125,131,150,159,165,170$. Na k. 11158 napıs: „Ex revisıone 1707”.

Op r a w a: pozostała jedynie część tylnej okładki. Skóra zdarta.

\section{$\mathrm{Nr} 3$}

96 (333) Łac. XV w. Perg. $36 \times 26$ cm. K. 241. Kol. 2. Oprawy brak.

Nicolaus de Lyra. Super Evangelia.

1) „Quatuor facies uni... Ezechielis secundum quid scribit beatus Gregorius” k. I: Mathaeus... hic est primus prologus beati Jeronımi, qui praeponitur evangelio Mathaei" k. 3.

2) „Evangelium secundum Marcum” k. 94v.

3) „Explicat evangelium Marci et incıpit prologus Lucae” k. 110v. „Facıes bovis” k. 111.

4) „Explicit postilla super evangelium Lucae. Incipit prologus in evangelium Johannis" k. 158v. „Facies aquilae” k. 159 X ,...praestante domıno nostro Jesu Christo, qui cum Patre et Spiritu sancto vivit et regnat in saecula saeculorum. Amen" $\mathrm{k}$. $241 \mathrm{v}$.

Pergamin biaky, karty mieszane: grube 1 cienkie. Na k. 1 i $241 \mathrm{v}$ u dolu napis: „Ex revisıone 1707 connotatum”.

Op rawa: oderwana. 
$\mathrm{Nr} 4$

97 (49) Lac. XV/XVI w. Perg. i papier. $40 \times 29 \mathrm{~cm}$. K. 171. Opr. deski w sk. $w s p l$.

Antiphonarium. Antyfony z nutami od adwentu na niedziele i święta, sanktorał i komunał.

1) Na przedniej okładce od wewnątrz wyklejka papierowa z wypisanym „Sanctus". Nuty na. 5 liniach. Na k. 1 nlb nap1s: „Dar... sta pissal, imię ma Opal(?)”.

2) Litanıa do Wszystkıch Swiętych na Wielką Sobotę. Wezwanie „Sancte Adalberte". Dopıski z nutamı na 3 linıach. K. $49 \mathrm{v}$.

3) $\mathrm{Na}$ dolnym marginesıe k. 61 napis: (imię zatarte) Listowski(?) Anno Domini 1572.

4) „Sancti Stanıslai Epıscopi” na k. 107v. Teksty z nutami dopisane na dalszych marginesach.

5) „De sancta Hedvigi” k. 157.

6) Na tylnej okładce naklejka papıerowa $z$ napisem: „In festis simplicibus canitur sic: Habemus ad Dominum" 1 inne z nutamı.

Kodeks uszkodzony. Pergamin w większości gruby, kremowy. Papierowe karty 164-171. 1 seksternion. Znak wodny: herb Habdank. Foliowanie: od k. 3 do 48 liczbamı rzymskımı, od 49 do 126 ărabskımı rẹką z XVI w., od 126 ręką z XIX w. Na k. 164 data 1585 r. Karty wyrwane: 1, 2, 13, 17, 23, po k. 32 jedna, 82, po k. 135 jedna, po 137 jedna, po 143 trzy. Ozdobne micjały na $k .7,51,53 \mathrm{v}, 54,61,73,73 \mathrm{v}, 89,128$, 143. Pod tekstamı nuty na 4 liniach i bez linii; są też i później dopısane. Kolọr czarny 1 czerwony. Inicjały: czerwony, nuebieski i zielony.

Oprawa: deskı powleczone skórą wytłaczaną. Slady po okuciach. Na grzbiecie napis: Antiphonarıum 49.

\section{$\mathrm{Nr}^{*} 5$}

98 (109) Eac. XIV w. przed 1424 r. Perg. $33 \times 22 \mathrm{~cm}$. K. 701. Kol. 2. Opr. deski $w$ sk. $w s p l$.

Raymundii Summa de vitiis et virtutibus et de casibus.

1) „Anıma, quod sit opınione $X$ Explicit summa de matrimonio. Amen. Finito libro sit laus et gloria Christo. Amen. Ista Summa (dwa wiersze wytarte, a po tym inną ręką): sacerdos si ante consecrationem".

2) "Incipit tractatus moralis de septem vitiis capitalibus" k. 8.

3) $\mathrm{Na}$ ostatniej stronie napis: „Anno Domini M-o CCCC XXIIII Mgr Nicolaus Pyser archidiaconus Sandomiriensis ${ }^{13}$ mortuus est, qui hunc librum cum aliis suis libris ecclesiae Collegiatae Sandomiriensi legavit".

Pergamin biały, cienki i gladki oraz gruby 1 chropowaty.

Pagınac ja k. 1-10, 1392 szpalty, 1 k. nib. Na k. ostatniej rysunek królowej i przysięgającego mlodzıenca. Napıs: „Ex revisione 1707 connotatum”.

Oprawa: przednia okladka zniszczona. Resztki okuć 1 guzów żelaznych. Na grzbıecie naklejka z napisem: „Summa de casibus" i napıs na oprawie: „Raymundi De casibus 109".

$\mathrm{Nr} 6$

99 (119) Łac. XIV/XV w. Perg. $28 \times 18 \mathrm{~cm}$. K. 255. Pismo 2 rak. Opr. deski w sk. wspt.

Biblia sacra. Skrót ksiąg historycznych.

13 Wiśnıewski, jw., s. 230. 
1) „Filii enim absterreantur uxoribus fratrum suorum innumeris fornicationibus” k. 1 .

2) „Incipiunt evangelia. Fuit in diebus Herodis regis Iudeae defluxis annis regni eius undetriginta sacerdos nomine Zacharias" k. 172.

3) „Incipiunt historiae Actuum Apostolorum. Anno decimo nono imperii Tiberii caesarıs"k. 212.

Pergamin biały gruby. Po k. 171 wyrwane 2 karty. Notatki marginesowe wspólczesne tekstowi i późniejsze. Pismo różnych rąk. Od k. 211 nowa ręka i foliacja z XIX w. Na k. 1 u dolu napis: „Biblia sacra ex revisione 1707 connotatum”.

Op r a w a: tylna okładka odarta ze skóry i nadniszczona.

\section{$\mathrm{Nr} 7$}

100 (300) Lac. XV w. (1452 r.). Papier. K. 523. Kol. 2. Opr. deski w sk. wspl.

Rękopis treści filologicznej.

1) "Notum quia sufficiens interdicit me vox abscondita” k. 1. „De consonantibus” k. 2 .

2) Expl.: „Finitae sunt quatuor partes in festo Margaritae virginis et martyris hora quasi 2-a post meridiem per me Agalbertunumm Tagarnopolitanensem (?)... $\mathrm{O}$ Marıa virgo poli... Item anno Domini millesimo quadringentesimo quinquagesimo secundo tonitruus et fulgur apparult et magnus sonus ferri in vigilia cathedrae sancti Petrı hora quasi quinta ante carnis privium".

Kodeks zdefektowany. Brak początku. Składki seksternów - ok. 87. Znak wodny: glowa wolu $\mathrm{z}$ kwiatkiem na dlugiej szypulce. Na wyklejce wewnętrznej przedniej okladki ślady nut i napisu, litery M.S.

Opr a wa: znıszczona. Resztka przednıej okładki. Część okucia żelaznego dolnego brzegu.

\section{$\mathrm{Nr} 8$}

101 (402) Lac. 1429 r. Papier i perg. K. 234. Kol. 2. Pismo 2 rak. Opr. deski $w$ sk. $w s p t$.

Franciscus de Abbate. Postilla.

1) „Lectio XII. Filii ex adulterio” k. 1. „Erunt signa in sole et luna” k. 2.

2) „Explicit postilla fratrıs Francisci de Abbate Astensi ordinis fratrum minorum. Scrıptus per Stanıslaum de Opatow dictum Goscz de anno Domini millesimo CCCC vicesimo nono. Orate Deum pro comparatore et scriptore".

Stan zachowania dobry. Pierwsza i ostatnıa k. pergaminowa. Reszta papier. Ok. 38 seksternów. Znak wodny: glowa wolu z kwiatem na długiej szypułce. Na k. 40v, 41 i dalszych dopiskı ınnej rękı.

Oprawa: skóra brązowa z ornamentamı. Okucia z brązu. Spinki zachowane. Na grzbiecie litery: M.S. i naklejka z numerem 402.

\section{$\mathrm{Nr} 9$}

102 (403) Lac. XV w. Papier i perg. K. 318. Kol. 2. Opr. deski w sk. wspl. Raymundus. Statuta summa super Sextum Decretalium.

1) „In nomine Domini. Amen. Isti sunt paragraphi fratris Raymundi” k. 1. „Explicit compendiosa collectio quorundam statutorum de Sexto Decretalium addita ad puncta confessorum. Deo gratias" k. 22v.

2) „Incipit prologus fratris Iohannis lectoris in priorem libellum quaestionum capitularium. Adsit principio Sancta Maria meo a.D. CCCC" k. 23. 
3) „Explicit prior pars summae confessorum... Incipit secunda pars huius operis. Primo de homicidio” k. 127. „Explicıt secunda pars summae confessorum. Incipit tertia pars huius de qualitate ordinandorum" k. 226.

Kodeks zdefektowany. Część kart wycięta. Papıer mieszany z pergaminem: 1 selsstern 12 karty pergamınowe. Znak wodny: kwiat $z$ liściem na galązce. Na odwrocie przedniej okładki napis: „Istum librum legat dominus Petrus" ${ }^{14}$. Na dolnym marginesie k. 1 napis: „Summa super Sextum Decretalium. Ex revisione 1707 connotatum”.

Op r a w a: skóra biała, podarta. Okucia powyrywane. Resztlki klamer. Na grzbiecie napis: M.S.

\section{Nr 10}

103 Lac. XVI w. (1567 r.) Perg. $28 \times 19 \mathrm{~cm}$. K. 140. Opr. deska w sk. wspl. Intonatorium Ecclesiae Sandomiriensis.

1) „....re elevan... Laetatus..." k. 1. Na k. $86 \mathrm{v}$ litera A ozdobna $\mathrm{z}$ wrysowanym $w$ nıą herbem i inicjałamı: M.C. 1567.

2) Na k. 104 litera G ozdobna z wrysowanym w nią herbem.

3) Explicit: „Altaria tua Domine virtutum rex meus et Deus meus” k. 140.

Pergamın biały gruby. Kodeks zdefektowany. Kilka kart na początku i końcu wyrwanych. Nuty na 5 liniach czerwonych. Inicjały i objaśnienıa czerwonym atramentem.

Opra wa: deski w skórze brązowej z wyciśniętymı obrazami biblijnymi. Napis: „Intonatorium Ecclesiae Sandomiriensis, 1568". Na środku zlocony odcisk: w kole Dziecię Jezus z krzyżem. Herb jezuitów, T.P. 1 w okole tekst: „In sole posuit tabernaculum suum Ps. 18". Okucia mosiężne z wyciśniętymi ornamentamı. Resztki pasków od klamer. Na grzbiecie napis: „Antiphonarium”.

$\mathrm{Nr} 11$

104 Lac. XIV/XV w. Perg. $29 \times 21 \mathrm{~cm}$. K. 190. Kol. 2. Opr. deski w sk. wspl.

Postilla sermonum per annum.

1) ,....ad proemium q. d. quod non cognovit rem nec attingat... tertia dominica... cum audisset Johannes in vinculis..." k. 1.

2) „...loquente Jesu ad turbas... dominica propria docuit...” k. $189 \mathrm{v}$.

Pergamin bialy gruby. Kodeks zdefektowany. K. 5 i $6 \mathrm{w}$ polowie urwane, K. 10 wyrwane. $\mathrm{Na} \mathrm{k}$. 34, 35, 36 i 37 ślady prób wyrwania. Na k. 55 róg obdarty. Po k. 189 trzy, a może i więcej kart wydarto. Na k. 127, 130, 153, 174 u dołu rysunki fantastyczne. Na ostatniej karcie napis: „Ex revisione 1707 connotatum”. 2 skrawki pergaminu zapisane ręką z XV w.

Op r a wa: deski w skórze biał̧ej. Okucia poodrywane.

$\mathrm{Nr} 12$

105 (155) Lac. 1437 r. Papier $31 \times 21$ cm. K. 392. Kol. 2. Opr. deski w sk. $w \operatorname{spt}$.

Monaldus. Summa super iure canonico completa.

1) Układ treści alfabetyczny: „De abbate X De usurıs”.

2) "Incipit prologus in summam fratris Monaldi de ordine minorum" k. 6.

3) „Explicit Summa fratris Monaldi de ordine fratrum minorum super iúre cano-

14 Może Piotr, kanonik sandomierski i kapelan Władyslawa Jagielly. Wiśniewski, jw., s. 232. 
nico completa. Scripta per me Andream de Żarnów pro domino Gregorio canonico et officiali Sandomiriensi ${ }^{15}$, nunc vero plebanr apud Sanctum Paulum extra muros Sandomirienses anno Dominı millesimo quadringentesimo trigesimo septimo, quo iubilaeus annus per Concilium Basiliense Regno Poloniae datus fuerit pro conversione Graecorum"' k. 392.

Stan zachowania dobry. Ok. 65 skladek seksternami. Znak wodny: glowa wolu, nad nıą krzyż $z$ wydłużonym ramienıem podłużnym. Na początku resztka pergaminu $\mathrm{z}$ tekstem liturgicznym i nutami na 4 liniach. Ozdobne inicjaly na $\mathrm{k}$. 6, 28, 51, 75, 100 , $119,123,160,171,199,204,211,259,261,269,335,363,391$.

O p r a w a: deskı w skórze białej. Resztkı olkućżelaznych i guzów brązowych.

$\mathrm{Nr} 13$

125 (9) Lac. XIV w. Perg. $28 \times 19 \mathrm{~cm}$. K. 98. Kol. 2. Opr. deski $w$ sk. wspt.

Postilla evangeliorum.

1) „Dominica prima in adventu Dommi. Incipiunt evangelia” $k .1$.

2) „Assumptione B.M.V. circa Collegiatam Ecclesiam sic canitur Sandomiriae” kompozycja z nutami; na tę samą melodię skomponowany hymn "Magnificat” $k .95$.

Kodeks uszkodzony. $U$ dolu k. 1 napis: „Postilla evangeliorum, ex revisione 1707 connotatum". Inicjaly ozdobne. Na k. 94 i na tylnej okladce podklejka z resztką tekstu hebrajskiego. Na ostatniej k. napis : „Ex revisione 1707 connot.”.

Oprawa: deski w skórze ozdobnej. Zachowały się tylko resztki skóry z wyciśniętymı ornamentami. Na grzbiecie napis: „Postilla”.

\section{$\mathrm{Nr} 14$}

126 (100) Lac. 1480 r. Papier i perg. $18 \times 17 \mathrm{~cm}$. K. 88. Opr. deski w sk. wspl.

Capitulare et ordo Missae.

1) „Ad tuam Christe sancto Ioanne Eleemosynario" k. 1. „Domme Iesu filì Dei vivi veniam peto coram sancta Matre tua... Stanislaus de Vidava 14LXXX-mo manu propria scripsit beati Augustinı ante accessum" k. 1v.

2) „In festo Eleymonıs sancti” (Sancti Ioannis Eleemosynarii) k. 62.

3) "Incipit rubrica Missarum dominica prima in adventu" k. 63.

4) "Capitulare istud per me Stanislaum Kaweczka de Vidava est comparatum in honorem praecelsae Dei Genitricis Mariae. Orate pro me ad Dominum. 1481" $\mathrm{k}, 88 \mathrm{v}$.

Papierowe karty 1-62. Znak wodny: mitra $z$ krzyżem na odwróconej koronie. Pergamin k. 63-88 gruby biały. Na k. 1 i 88v napis: „Ex revisione 1707 cinnotatum”.

Oprawa: deskı powleczone skórą z wyciśniętymi ornamentami. Na przodzie kwadraty. Od wewnątrz okładkı wyklejone papierem ze starodrukiem.

$$
\text { Nr } 15 \text {. }
$$

(116) Lac. 1273 r. Perg. $32 \times 22$. K. 119. Kol. 2. Opr. deski w sk. wspl. Petrus de Taranthasia ${ }^{16}$. Super 1-mum Sententiarum.

1) „Liber primus. Distinctio prima... Dent in cognitionem eius...” k. 1.

2) „Liber I. Dıstinctio XLVII... prastare eodem Redemptore qui est benedictus in

15 Wiśnewski, jw., s. 82:

18 Cysters, abp Tarentaise jako Piotr I od r. 1124 do śmierce $w 1140$, lub raczej Piotr II, abp tejże stolicy, cysters, zmarly w 1174, w: Lexikon für Theologie und Kirche, t. 8, szp. 381. Nasuwa się domysl, że kodeks pochodzl z ośrodka cysterskiego, moze z Koprzywnicy 
saecula saeculorum. Amen. Explicit liber primus Sententiarum... Petrus de Tarterhavate [?] perscriptum fine mense iunii anno Domini $\mathrm{M}^{\circ} \mathrm{C}^{\circ} \mathrm{LXX} \mathrm{IIII}^{\circ}$ " k. 119.

Kodeks dobrze zachowany. Pergamin gruby biały. Pismo 1 ręki, 51 wierszy na stronı. Na k. 1 i 119 napis: „Petrus, Super primum Sententiarum... Ex revisione 1707 connotatum".

Opraw a: Desku powleczone skórą białą gładką. Na okładce przedniej tytul zatarty. Są tam 3 podklejkı pergaminowe z tekstami różnych rąk XIII-XV w. Na tylnej okładce 2 wyklejki pergamınowe. Jedna $z$ tekstem liturgicznym. Druga zawiera spis rzeczy. Paski do spinanı. Na grzbiecie napis: „Petrus, In 1-mum librum, 116”.

Kodeks mikrofilmowany przez Bibliotekę Narodową w Warszawie, nr 22538 . Zlożony w szufladzie stołu posiedzeń.

\section{$\mathrm{Nr} 16$}

(359) Lac. 1338 r. Perg. $33 \times 22 \mathrm{~cm}$. K. 121. Kol. 2. Opr. deski w sk. wspl. Petrus de Taranthasia. Super secundum Sententiarum.

1) „Qui vivit in aeternum, creavit omnia” k. 1.

2) „Expliceat, inter scriptores eat”. Spıs: rubryk dystynkcji XLI: K. 120v.

Kodeks dobrze zachowany. Pergamin biały cienki. Na k. 1v litera „O” ozdobna. Na k. 120v napis: „Ex revisione 1707 connotatum”.

O p r a w a: deskı w podwójnej skórze białej gładkıej. Na wyklejce przedniej okładki napis: "Librum magistri theologiae Super secundum Sententiarum anno Domini $\mathrm{M}^{\circ} \mathrm{CCC}^{\circ} \mathrm{XXX}^{\circ} \mathrm{VIII}^{\circ}{ }^{\circ . .}$ Nicolaus...(?) ${ }^{12}$. Utrum peccatum sit voluntarıum". Początkowe 24 wiersze zatarte. Spis rubryk, dalszy ciąg z ostatniej okladki. Na grzbiecie napis: „Petrus de Voragıne(?)". Naklejka 359. Główki gwoździ brązowych.

Kodeks mikrofilmowany przez Bibl. Nar, w Warszawie, nr 22 540. Przechowywany w szufladzie stolu posiedzeń.

\section{$\mathrm{Nr} 17$}

(363) Lac. XIII/XIV w. (1300 r.). Perg. $44 \times 27$ cm. K. 309. Kol. 2. Opr. deski-w sk. $w s p t$.

Guido Ardyavil(?). Super Decretales.

1) „Reverendo in Christo patri... epıscopo Sabinensi Guido de Baysiobonensi” 18 k. 1 .

2) „Explicuntur distinctiones. Quidam hıc incipit...” k. 85v 186.

3) „Sequitur tractatus de poenitentia" k. 270v.

4) W tekście data roczna MCCC na k. 308.

Pergamın biały cienkı. Pismo 1 ręki, 77 wierszy na stronie. Na k. 1, 86, 271 ozdobne litery z popiersıami osób, całymı postaciami lub symbolami. Notatki marginesowe.

Oprawa: deski w bıałej skórze gladkiej. Przy okładce przedniej tekst prawniczy w 2 kolumnach. Resztkı okuć. Na grzbiecıe napis: „Guido, Super Decretales, 363”.

\section{$\mathrm{Nr} 18$.}

(110) Łac. XIII/XIV w. Perg. $35 \times 24 \mathrm{~cm}$. K. 308. Kol. 2. Pismo 2 rak. Opr. deskiw sk. wspl.

Gregorii Decretales.

17 Moze Mikołaj Gaworek, kanonik sandomierskı, związany z klasztorem w Wąchocku. Wiśniewskı, jw., s. 67.

18 Por. J.F. Schulte: Geschichte der Quellen und Literatur des canonischen Rechts, t. II, Graz 1956, s. 186-190. 
1) Teksty prawnicze k. 1. Spis rozdziałów „De summa Trinıtate - De regulis iuris" k. 1v-2. Zestawienie cnót w kwadratach i innych figurach geometrycznych k. 2v.

2) „Gregorius episcopus, servus servorum Dei... Liber I” k. 3. „Liber II. De iudiciis. Ex concilio Africano. De Quodvultdeo Centuriensi episcopo” k. 72. „Liber III. De vita et honestate clerıcorum. Ut laıci. Ex concilio Moguntino" k. 144. „Liber IV. De sponsalibus et matrimonio. De Francia. Ex concilio Triburensi" k. 219. "Liber V. De accusationibus, inquisitionibus et denuntiationibus. Si legitimus" k. 243.

3) „De regulis 1uris” k. 307v. „Explicit apparatus ‘quinti libri Decretalium” k. 308. Teksty prawnicze k. 308v.

Kodeks dobrze zachowany. Pergamın biały cienki. Na marginesach glossy pisane jaśniejszym atramentem żółtawym. Litery rozpoczynające teksty ksiąg ozdobne z miniaturamı. Na k. 143 głowa czlowieka - zmysły. Na k. 1 i 308 napis: „Ex revisione 1707 connotatum".

Op r a w a: deski w bıałej gładkıej skórze. Guzy mosiężne. Paskı do zapinania.

Kodeks złożony w szufladzıe stołu posıedzeń.

\section{$\mathrm{Nr} 19$}

(122) Lac. XIII/XIV w. Perg. $29 \times 22 \mathrm{~cm}$. K. 116. Kol. 2. Pismo 2 rak. Opr. deski w sk. wspl.

Divus Thomas. Super primum Sententiarum.

1) „Distinctio VII. Esse volitum a Deo potest esse volitum eldem" k. 1 (XIX).

2) „Ut omnes teneantur ad conformitatem quae est in volito... Cul est honor et gloria per infinita saecula saeculorum. Amen." k. 116-116v.

Kodeks uszkodzony. Pergamin bialy gruby. Foliacja od k. XIX do CXXXV. K. LXXVII-LXXXIV wydarte. Pierwsza ręka pisała od początku do $\mathrm{k}$. LV i od LXXVII do końca. Druga resztę. Na k. pierwszej i ostatniej napis: „Ex revisione 1707 connotatum".

O p r a w a: deskı w białej gładkiej skórze. Jedna taśma do zapinania ođerwana.

Kodeks mikrofilmowany w Bibl. Nar. w Warszawie, nr 22539 . Zlożony w szufladzıe stolu posiedzeń.

\section{$\operatorname{Nr} 20$}

(115) Łac. XIII/XIV w. Perg. $29 \times 20 \mathrm{~cm}$. K. 382. Kol. 2. Pismo 2 rąk. Opr. deski w sk. wspl.

Divus Thomas. Super quartum Sententiarum.

1) Spis tytułów: „Distinctio I-L. Liber IV. Distinctio I. Misit verbum suum et sanavit eos" k. $1-4$.

2) ,....ad quem omnia ordinantur, cul est honor et gloria in saecula saeculorum. Amen. Explicit IIII Sententiarum, quem scripsit Thomas de Aquino ordinis praedicatorum" k. 382v.

Kodeks dobrze zachowany. Pergamin kremowy gruby. Na k. 4 litera „M", ozdobna - miniatura. Po k. 178 ślad wydarcia. W końcu napis: „Ex revisione 1707 connotatum".

O praw a: deski powleczone białą skórą. Guzy mosiężne na podkładkach o 3 ramionach. Na przednıej i tylnej okładce napisy różnymi rękami: „Thomas, Super quartum Sententiarum". Napis grzbietowy: „Thomas in 4 Sententiarum, 115”.

Mikrofilm Bibl. Nar. W Warszawie nr 22629 . Kodeks zlożony w szufladzie. 
$\operatorname{Nr} 21$

(355) Lac. XIII/XIV w. Perg. $36 \times 25 \mathrm{~cm}$. K. 367. Kol. 2. Opr. deski $w$ sk. wspl.

Jacobus de Voragine. Sermones de Sanctis.

1) „Festo Andreae apostoli sermo. Vestigiis eius secutus est pes meus” $k$. 1 .

2) „Sermo de dedicatione. Venit Filius hominis quaerere... salvam faceret et in paradiso collocaret" k. 367 .

Kođeks dobrze zachowany. Pergamin biały średniej grubości. Na k. 1 litera „V" ozdobna, kolor czerwony i niebieski. Napisy: ,Sermones de Sanctis Jacubıni de Voragine protunc manere debent in Ecclesia Sandomiriensı. Comparatus per Fabrium(?) Martinum ${ }^{19}$. Oretur pro magistro Johanne dicto Pfuern (?) et est legatus... Ecclesiae Sanctae Mariae Sandomiriensi”. Potem: „Ex revisione 1707 connotatum”. „Taxatum saeculo XV 16 martii".

Opraw a: deski w skórze białej gładkiej. Slady po guzach i klamrach. Napis grzbietowy: „Jacobı de Voragine De Sanctis”. Naklejka nr 355.

\section{$\mathrm{Nr} 22$}

(420) Lac. 1302 r. Perg. $36 \times 25$ cm. K. 330. Kol. 2. Pismo 2 rak. Opr. deski $w$ sk. wspl.

Nicolaus de Lyra. Super maiores prophetas.

1) „Ysayas, Hierusalem. Visio Ysaye. Hic accendendo ad foras tractatus, qui est divisio libri" $\mathrm{k} .1$.

2) Po zakończeniu rozdziału LXVI: „Explicit postilla super Ysayam edita a fratre Nicolao de Lyra de ordine fratrum minorum" k. 168.

3) „Incipit postilla super Yeremiam edita a fratre Nicolao de Lyra ordinis fratrum minorum" k. 168v.

4) „Lamentationes Yeremiae. Quomodo sedet" k. $175 \mathrm{v}$.

5) „Baruch. Et haec verba libri post librum Tobiae” k. 184v.

6) „Explicit postilla super librum edita a fratre Nicolao de Lyra de ordine fratrum minorum... venerabili doctore super Ezechielem et prophetas sequentes. Aperti sunt tibi". k. 192v.

7) „Explicit postilla super Ezechielem edita a fratre Nicolao de Lyra et per me completa cum Dei adiutorio anno Domini $\mathrm{MCCCII}^{\circ}$ in vigilia Sanctae Trinitatis" k. $280 \mathrm{v}$.

8) „Danieli autem dedit Deus intelligentiam” k. 281.

9) „Explicit postilla super Danielem” k. 330.

Kodeks dobrze zachowany. Pergamin biały gruby. Po k. 12 ślady karty wyciętej. K. 62v, 196v-197, 257 w całoścı lub w części czyste. Na k. 192v litera „A" ozdobna w kolorze czerwonym i niebieskım. Na k. 1 i 330 napıs: „Ex revisione 1707 connotatum”.

O prawa: deski grubości $1 \mathrm{~cm}$ powleczone $\mathrm{w}$ bialą skórę. Zachowal się jeden pasek do spinania. Naklejka na grzbiecie: „Lyra Super Maiores Prophetas, 331”.

Kodeks mikrofilmowany przez Bibl. Nar. w Warszawie nr 22484 . Zlożony w szufladzie stolu.

19 Może Marcin z Krakowa, kantor sandomerski z I pol. XIV w. Wiśniewski, jw., s. 201. 
$\mathrm{Nr} 23$

(342) Lac. 1326 r. Perg. $42 \times 26$ cm. K. 278. Kol. 2. Opr. deski w sk. wspt. Liber Decretalium.

1) „Iurıs canonici decreta... De Summa Trinitate et fide et de constitutionibus” k. 1-1v. Spıs rozdzıałów późniejszy. „Gregorıus epıscopus”. Glossa na marginesıe.

2) Drzewo genealogıczne. Rysunki osób 1 ornamenty w kolorach: niebieskim, zielonym, czerwonym i żóltym. K. 187v.

3) „Explicit liber Decretalium. Qui scripsit, sciebat et longo tempore vivat. Amen”. K. $248 \mathrm{v}$.

4) "Innocentius episcopus servus servorum Del universitati magistrorum et scolarum Bononiae. Tum nuper in Concilio Lugdunensi" k. 250.

5) „Incipiunt constitutiones novellae... Gregorii papae $\mathrm{X}$ in generali Concilio Lugdunensi. Gregorius episcopus servus servorum Del venerabili fratri episcopo et dilectis filiis unıversis... et doctoribus et scolaribus Paduanensibus salutem" k. 261.

6) „Nos Cotricus (?) praepositus ecclesiae Del... actum est añ̄o Domıni millesimo tricentesımo vicesımo sexto. Nos Gotfridus decanus ecclesiae novl monasterii Herbipolensi... actum anno Domıni $\mathrm{M}^{\circ} \mathrm{CCC}^{\circ} \mathrm{XXVI}{ }^{\circ} " \mathrm{k} .277 \mathrm{v}$.

Kodeks był często $\mathrm{w}$ użyciu, przypuszczalnie w klasztorze. Pergamin biaky cienki. Późniejsze dopıski róznych rąk. K. 249 czysta. Na odwrocıe notatka: „Tum res gesta...”. Notatka: „Ex revisione 1707 connotatum”.

Op r aw a: deskı powleczone skórą bıałą z wytłoczonymi ornamentami $i$ orł̧ami z koroną. Okucia mosıężne, ozdobne. Paski od klamer oderwane. Naklejka grzbietowa: „D. Gregorii scriptus. Innoc. 343”.

\section{$\mathrm{Nr} 24$}

(114) Lac. 1335 r. Perg. $29 \times 21 \mathrm{~cm}$. K. 190. Kol. 2. Opr. deski w sk. wspi. Liber Pantheon magistri Gottifredi ${ }^{20}$. Traktaty teologiczne i historyczne.

1) „De Jacobo apostolo Alphel origo" k. 1.

2) ,...ab apostolo relictus et ibique in pace sepultus est” k. 190. Kolofon: „Explicit liber iste cul nomen Pantheon, scriptus per magistrum Gottifredium (?)... canonici Cracoviensis, primo tractatu de divina essentia; deinde de anima humana, postea do veteri et novo testamento et de diversis imperatoribus ac regibus... in crastino sancti Jacobi sub anno $1335 "$ ".

Kodeks dobrze zachowany. Pergamin kremowy. Na stronach verso foliacja liczbami rzymskımı od IX do CXCVII. Dopıski marginesowe dotyczące treści dzieła, rzadkıe. Inicjaly duże stylizowane farbą czerwoną. Rubryki. Liczne miniatury: k. 86v (XCIV) 5 minıatur w tekście ze scenami biblijnymi 1 historycznymi; k. $87(\mathrm{XCV}) \rightarrow 8$ minıatur, verso -1 ; k. 88 (XCVI) -3 miniatury, verso -1 ; k. 89 (XCVI ?) -2 miniatury; k. 90 (XCVIII) -3 miniatury. Obrazy są w 3 do 5 kolorach: brązowy, czerwony, niebieskı, zıelony i żółty. Obwódkı rysunków ciemne. Płaszczyzny kropkowane lub kreskowane. Napisy na k. 1 (IX) 1190 (CXCVII) : „Ex revis. 1707”.

20 Prace nad tym rękopısem prowadził ks. Józef Rokoszny. Ogłosił: Gottifredi Pantheon w „Kron. Diec. Sand.”, r. 7: 1914, s. 11-15; Gottifredi Pantheon - wiadomość o rękopisie $z$ XIV w. znajdujacym się w Bibliotece Kaptuly Katedrálnej $w$ Sandomierzu, w: Wyd. Tow. Nauk. Warsz., Wydz. Językozn. 1 Lit., Pr. Komis. do Bad. nad Hist, Lit 2 Ośw., t. I, Warszawa 1914, s. 363-378; Komunikat o znajdującym się w Sandomierskiej Bibliotece Kapitulnej rękopısie pt. Gottifredi Pantheon $z$ r. 1335, w: Spraw. Kom1s. do Bad. Hist. Szt. w Polsce, t. IX, szp. CCXXXIV-CCXXXV. Prace nad miniaturami tegoż kodeksu prowadzone są w Instytucie Historii Sztuki PAN w Warszawie. 
Op rawa: deski powleczone gladką skórą podwójną. Na spodzie skóra cieńsza kremowa. Na wierzchu - grubsza szara. Na tylnej okładce blaszka mosiężna od pasków spınających kodeks. Na przedniej ślady po 2 guzach ochronnych. Na przedniej i tylnej - po blaszkach w środku okładkı. Na odwrocie okladki przednıej napis olówkıem: „Fotografowany 1 opısany w Sprawozdanıu Komisji Historii Sztukı Akademii Krakowskıej 1912, w Sprawozdanach Tow. Nauk. Warsz. i Kronıce Diecezji Sandomierskiej, X. Rokoszny”. Na grzbiecie naklejka $2 \mathrm{~cm}$ szeroka z XIV w.: „Liber Pantheon magıstrı Gottifredi" I napıs prawdopodobnie z 1707 r.: "Gottifredi Pantheon, $114 "$ ".

Kodeks mikrofilmowany przez Bibl: Nar, w Warszawie, nr 22780 . Zlozony w szufladzie.

\section{$\mathrm{Nr} 25$}

(112) Lac. 1369 r. Perg. $31 \times 21 \mathrm{~cm}$. K. 279. Kol. 2. Opr. deski w sk. wspl. Nicolaus Lyra. Super Evangelia.

1) „Incipit opusculum sive lectura ...Nicolal de Lyra super Evangelium IMathaei. Quatuor facies" k. 1.

2) „Hic incipit prologus super Evangelium Marci. Facies leonıs” k. 103v.

3) "Sub anno Dominı millesimo $\mathrm{CCC}^{\circ} \mathrm{L} \mathrm{X}^{\circ}$ nono ferla IIII post festum Paschae explicit postilla super Evangelium Marci"' k. 126.

4) „Explicıt glossa super Evangelia Lucae. Facies aquilae” k. 179.

5) „Explicit glossa super Evangelium Johannis anno Dom. $\mathrm{MI}^{\circ} \mathrm{CCC}^{\circ} \mathrm{LXIX}{ }^{\circ} \mathrm{k}, 279$.

Kodeks dobrze zachowany. Perg. 'bıaly crenki. Inıcjały ozdobne na k. 1, 3v, 5, 5v, $10,12 \mathrm{v}, 14 \mathrm{v}, 17,22 \mathrm{v}, 30,34,38,43,46 \mathrm{itd}$. Na karcıe przy przedniej okładce napıs: „Iste liber $N$. Lyra donatus per Nicolaum olim vicedecanum vicariorum Ecclesiae Collegtatae Sanctae Mariae Sandomıriensi vicariis Ecclesiae Sandomiriensis comparatur pro IIII marcis latorum grossorum monetae Pragensis, oretur pro eo". Na k. ostatniej napis: „Ex revisione 1707 connotatum”.

O p r a w a: deskı w skórze bıałej gladkiej. Slady okuć. Na okładce tylnej napıs: „Non debitum in Starosiedlicze quod Dominus Stanıslaus cmetho de Bidzıny manu propria obligatus est in actis solemniter duarum marcarum anno Dom, $\mathbf{M}^{\circ} \mathrm{CCCC}^{\circ}$ quinto". Na grzbiecie naklejka: „Opus N. Lyrae Super Evangelium Mathaei”. Napıs: „Lyra, In Evangelia, 112” ręką z XVIII w.

\section{$\mathrm{Nr} 26$}

(330) Lac. XIV w. Perg. $35 \times 26 \mathrm{~cm}$. K. 249. Kol. 2. Opr. deski w sk. wspl.

Nicolaus Lyra. Supęr Iosue. Iudicum, Ruth. Są dalsze księgi.

1) „Introduces eos et plantabís eos in montem hereditatis tuae... finis libri Ruth" k. 1.

2) „Malachias... non est forte quia adventus..." k. 249.

Kodeks dobrze zachowany. Pergamin biały średnej grubości. K. 45-49 czyste. Napis na końcu: „Ex revisione 1707 connotatum”.

Oprawa: deskı w skórze bıałej gładkıej. Guzy ochronne. Slady klamer. Na okladce napis: "Lyra super Iosue, Iudicum et Ruth et libros Sapientiae et super minores Prophetas". Napis na grzbiecie: „Lyra, Super Iudices, Iosue, Ruth”.

Nr 27

(47) Lac. Druga poł. XIV w. Perg. $43 \times 32 \mathrm{~cm}$. K. 280. Kol. 2. Opr. deski w sk. wspl.

Venerabilis Bedae Homiliae. 
1) „Incipiunt homiliae ab adventus dominica prima. Lectio sancti Evangelii secundum Mathaeum. Omelia venerabilis Bedae presbyteri de eadem lectione. Puto res ista exıgit, ut quaeramus frequenter". k. 1. Układ: temporal, sanktoral i komunal. Sa homilie św. Augustyna (k. 31v), św. Grzegorza (k. 46), św. Jana Chryzostoma (k. 48), św. Leona W. (k. 53v), św. Hieronima (k. 55v), św. Anzelma: „Omelia venerabilis Asselini (!)" - na marginesie poprawiono: „Anselmi archiepiscopi” k. 265. Na k. 157v "In die Pentecostes” nie dopisano imienıa autora, pozostalo tylko: „Omelia de eadem lectione".

2) „Lectio sancti Evangelii secundum Johannem... et omnem qui fert..." k. $280 \mathrm{v}$.

Kodeks dobrze zachowany. Pergamin bialy gruby Rzadkie sa karty cienkie. Po k. 4 ślad wydarcia. Są miejsca wolne na rubryki, nie zapısane szpalty, nie dokończone ozdoby liter. Rzadkie dopiski margınesowe. Początkowe litery „I" są więcej ozdobione. Na początku i na końcu napis: „Ex revisione 1707 connot.”

O p r a w a: deski gruboścı $1 \mathrm{~cm}$ w skórze bıałej gładkiej. Okucia i guzy żelazne. Klamry zachowane. Zakładkı ze skóry okrywające ksı̨̨gę nad górnym margmesem. $\mathrm{Na}$ wewnętrznej stronie przedniej okładkı spis rozdzıłłów. Na tylnej napis: „Primo duodecim calices deaurari... in una monstrantia destructa". Inny naprs: „Anno Domini MCCCC quinto racı facta est... dominus praepositus et dominus cantor"; następuje wyliczenie ofiar złożonych przez członków kapituły. Na grzbiecıe napis: „Bedae Homiliae, $47^{\prime \prime}$.

$$
\text { Nr } 28
$$

(3) Lac. XIV w. Perg. i papier. $43 \times 34 \mathrm{~cm}$. K. 193. Kol. 2. Opr. deski $w$ sk. $w$ spl.

Biblia sacra cum prologo Sancti Hieronymi, Genesis ad Paralypomenon.

1) ,...sit, tamen Paulus sapıentiam loquitur... Invenit Philippus...” k. 1. „Explicit Genesis. Incipit liber Exodus" k. 24v.

2) „Explicit Deutoronomium. Incipit praefacio sancti Hieronymi presbyteri in Iibrum Iosue" k. 90.

3) „Explicit liber Iudicum. Incipit liber Ruth” k. 112v.

4) „Explicit liber Regum IIII. Incipit praefacıo sancti Hieronymi presbyterı... Incipit liber Paralypomenon"k. 167v-168.

5) Rozdzial XXII. „Duodecim annorum in domo hac... qui elegit de cunctis..." k. $193 \mathrm{v}$.

Wkładka: 3 karty papieru $31 \times 19 \mathrm{~cm}$ z tekstem kaznodziejskim z XV w. Znak wodny: glowa wolu $\mathrm{z}$ kwiatkiem na długiej szypułce.

Kodeks zdefektowany. Po k. 2 wydarto kartę z początkiem Genesis. Po k. 113 wyrwano karty $z$ początkiem Iudicum. Na końcu ślady po 3 kartach wyrwanych. Na k. 36 wycięto inicjał, $11 \times 7 \mathrm{~cm}$. Litery duże $4-5 \mathrm{~mm}$ jakby rysowane. Na początku i na końcu napis: „Ex revisione 1707 connotatum”.

O pra wa: deski grubości $1,5 \mathrm{~cm}$ powleczone skórą bialą gładką. Pod nıą skóra gładka brązowa. Okucıa żelazne na podkładce $\mathrm{z}$ czerwonego sukna. Klamry uszkodzone.

\section{$\mathrm{Nr} 29$}

(45) Lac. XIV w. Perg. $47 \times 35 \mathrm{~cm}$. K. 184. Pismo 3 rak. Opr. deski w sk. wspl.

Liber Tobiae - ad Malachiam.

1) „,...ciebas eleemosynas et sepulturas, Tobias vero..." k. 1.

2) "Explicit liber Iudith. Incipit praefacio in librum Hester..." k. 12. 
3) „Explicit liber Job. Incipit praefacio sancti Hieronimi presbyteri in Parabolas Salomonis" k. 21.

4) „Explicit Isajas propheta. Incıpıt praefacıo in Jeremiam prophetam” k. 90.

5) „Explicit Malachıas propheta” k. 183.

Kodeks zdefektowany. Pergamin bialy gruby. Litery jakby rysowane. Ozdobne inıcjały na początku ksıąg. Na k. 183-184 tylko miejsce na inicjały. Po k. 3 znak wyrwanı. To samo po k. 48 i 183. Na początku I końcu napis: „Ex revisıone 1707 connotatum".

Op r a wa: deskı w podwójnej skórze. Okucia 1 guzy żelazne. Klamry zachowały sıę. Przy tylnej okladce napis ołówkıem: Aleksander Jezowskı 1851. Rozn (?) Mirosław Wiesıłowski. Napis grzbietowy: „Tobia ad Malachiam, 45”.

\section{$\mathrm{Nr} 30$}

Łac. XIV w. Perg. $37 \times 26 \mathrm{~cm}$. K. 507. Kol. 2. Opr. deski w sk. wspl. - Biblia sacra.

1) „Incipıt epistola beati Hieronymi presbyterı ad Paulinum... Frater Ambrosius..." k. 1 .

2) „Incipit liber Machabaeorum”... k. 341.

3) „Interpretationes et canones” k. 465.

Kodeks uszkodzony. Pergamin bıały gruby. Pierwsze litery każdej ksıęgı iluminowane. Na k. 1 litera „F” z obrazkiem św. Hieronima w kapeluszu kardynalskim i w plaszczu purpurowym ujmującego lapę czarnego lwa. Minıatury w złocie i w kolorach. Szereg minıatur wycıętych. Na końcu napıs: „Biblia sacra integra. Ex revisione connotatum 1707".

Oprawa: deskı w skórze bıałej gladkiej. Narożnikı kute w mosiądzu. Guzy 1 ślady klamer. Przednıa okładka oderwana. Deski przelupane. Grzbıet znıszczony.

Kodeks przechowywany w szufladzie.

\section{$\mathrm{Nr} 31$}

(43) Lac. XIV/XV w. Perg. $36 \times 25 \mathrm{~cm}$. K. 356. Kol. 2. Pismo 2 rak. Opr. deski w sk. ẃspl.

Astesani Summa de Casibus, pars II.

1) „Liber quartus. Titulus primus librı quarti, in quo agitur de sacramentis" (chrzest - Eucharystia) k. 1.

2) „Explicit liber quartus de Summa fratris Astesani de Asti ordinis fratrum mınorum. Sequitur quintus" (o pokucie) k. 37v.

3) „Explicit libet quintus. Incipıt sextus” (o kaplaństwie) k. 100.

4) „Explicit liber sextus Summae Casuum per manus A.T. (?)” k. 226.

5) „Assiz principio stant Maria meo. Isti sunt tituli septimı libri qui est de censura Ecclesiae. Quid est excommunicatio et de speciebus eius" k, 228.

6) "Finis illius septimi libri. Incıpit liber octavus in quo tractatur de matrimonio" k. $289 \mathrm{v}$.

7) ,...pater eam dotare tenetur nisi unum et dignum elegerit etc. Deo gratias. Explicit liber octavus Summae de Casibus editae a fratre Asterano de Ast de ordine fratrum minorum" k. 356.

Pergamin brały gruby. Na końcu napis, „Ex revisione 1707 connotatum”.

O p r a wa: deski gruboścı $1 \mathrm{~cm}$ w skórze białej. Paskı wiązące. Na grzbıecie naklejka z napisem: „2-da pars Casuum Astesani”. N. 43.

Kodeks mikrofilmowany przez Bibl. Nar. w Warszawie, nr 22 485. Przechowywany w szufladzie. 
$\mathrm{Nr} 32$

(107) Łac. XIV/XV w. Perg. $41 \times 30 \mathrm{~cm}$. K. 240. Kol. 2. Pismo 2 rqk. Opr. deski w sk. wspl.

Missale.

1) „,...singuli in suam civitatem. Ascendit autem Joseph a Galilea..." k. 1 (X).

2) „Dilexısti iustitiam” dzień św. Lucji. Zakładka papierowa z tekstem brewiarzowego oficjum o N.M.P. (Niepokalane Poczęcıe). Napıs: „Jacobus Mirkowski (?) k. $156 \mathrm{v}$.

3) „Pro defunctis...”. „Et scio quia quaecumque poposcerıt a Deo...” k. 240.

Kodeks zdefektowany. Pergamin kremowy, nadnıszczony, więcej grubych kart. Po k. 14, 80 i 88 ślady wyciętych kart. W oficjach świątecznych pierwsze litery ozdobne. Niektóre rybryki pisane czarnym atramentem a podkreślone czerwonym. Na prawym marginesie bocznym i dolnym k. 19 napis: „Sczuka (?) canonicus Sendzigal (?)... Joannes a vicecustodi (?), Duczek, Martinus Sczebel, Derdek, Byeski i in.". Rzadkie dopiski na marginesach. Na końcu napis: „Ex revisione 1707 connotatum”. Foliacja liczbami rzymskimi X-CLXXI i arabskimi.

Op rawa: deski ze śladem skóry na przedniej okkadce i na grzbiecie. Slady okuć. Na wewnętrznej stronie przedniej okładki 2 warstwy papieru z tekstami liturgicznymi. W dolnej części "Gloria in excelsis Deo" z nutamì na 5 liniach (różne intonacje). Na tylnej okładce - modlitwy dopisane różnymi rękami. Na grzbiecie napis: „Missale, 107”.

$\mathrm{Nr} 33$

(120) Łac. 1407 r. Perg. $25 \times 17 \mathrm{~cm}$. K. 281. Kol. 2. Pismo wielu rakk. Opr. deski $w$ sk. wspl.

Jacobus de Voragine. Sermones. Po dwa lub trzy kazania na każdą niedzielę i święto.

1) „Incipit prologus super Jacobum de Voragine. Idemque labilis iste decessus. Dominica Ia adventus Domini" k. 1.

2) Wklejona mniejsza karta papierowa z rozwaźaniem moralnym. Ręka późniejsza k. 58.

3) „Dominica XXV” k. 268v. „Sermo ultimus” k. 272.

4) „Explicit Jacobus de Voragine scriptus et completus anno Domini $\mathbf{M}^{\circ} \mathrm{CCCC}^{\circ} \mathrm{VII}^{\circ}$. Laborıs finis adest operis mercedem prosecutus" k. 274. Spis mów k. 275.

5) „Iste liber est Petri de Posnania vicarii Ecclesiae Collegiatae Sanctae Mariae Sandomiriensis, quem comparavit ibidem pro media tercia marca. Oretur pro eo". Na drugiej kolumnie 12 wierszy: „Ave rosa de Jericho" k. 281.

Kodeks uszkodzony. Pergamin gruby biały. 5 kart nie zapisanych. Paginacja $A_{1}-A_{25}, B_{1}-B_{30}$ itd. Miejsca na ozdobne litery na k. 1, 93, 130v. Dopiski marginesowe. Na początku i na końcu napıs: „Ex revisione 1707 connotatum”.

Opr a w a: deski w skórze białej. Pozostały resztki skóry i 1 pasek do spinania. Na grzbiecie odartym ze skóry napis: "Jacobus de Voragine, 120".

Kodeks mikrofilmowany przez Bibl. Nar. w Warszawie, nr 22 537. Przechowywany w szufladzie.

Nr 34 ,

(329) Еac. Pocz. XV w. (1416 r.?). Perg. $35 \times 25$ cm. K. 264. Kol. 2. Opr. deski w sk. wspl.

Nicolaus Lyra. Super Pentateuchum. 
1) „Haec omnia liber vitae...” (Prologus) k. 1.

2) „Explicıt liber [Deuteronomii]” k. 264.

Kodeks zdefektowany. Pergamin bialy gruby. Inicjaly czerwone.

Oprawa: deski w skórze bialej. Guzy i paski. Na przedniej okładce napis: „Lyra, Super Pentateuchum”. Na odwrocie 1416. Na grzbiecie napis: „Lyra, Super Pentateuchum". Naklejka nr 329.

\section{Nr 35}

Lac. Pocz. XV w. (1424 r.). Perg. $23 \times 15 \mathrm{~cm}$. K. 378. Opr. deski $w$ sk. wspl.

Raymundus. Summa de Casibus. Z glossami.

1) „Anno Domini $\mathrm{MCCCC}^{\circ} \mathrm{XXIII}{ }^{\circ}$ librum hunc... Nicolaus Peyser... Sandomiriae datus ad librarium vıcariorum Ecclesiae Sandomırıensis.". Ponıżej wıersz łaciński k. $1 \mathrm{v}$.

2) „Liber I. De symonia” k. 3. „Licet dare et accipere aliquod pro spirituali” k. 6.

3) "Liber II. De homıcidio" k. 95v.

4) "Liber III. De qualitate or'dinandorum" k. 167v.

5) „Liber IV. Quoniam frequenter in foro" k. 328. „Explicit corrector super matrımonıo. Explicıt summa de matrımonı\%" k. 378.

Kodeks zdefektowany. Pergamin biały cıenki. Inıcjaly kolorowe i ozdobne. Slady po wydartych kartach. $\mathrm{Na} \mathrm{k}$. $327 \mathrm{~V}$ napis: „Anno Domını $\mathrm{MCCCCXXXV}^{\circ}$ venıt Petrus Miroslar de Cracovia Sando...". Na k. 3 i 378 napis: „Ex revisione 1707 connotatum”. Glossy.

O praw a: zniszczona. Skóra zdarta. Z deskı tylnej pozostała trzecıa część. Slady po paskach wıążących.

Kodeks mikrofilmowany w Bibl. Nar. w Warszawıe, nr 22542 . Nie ma żadnej sygnatury. Przechowywany w szufladzie.

\section{$\mathrm{Nr} 36$}

(6) Lac. XV w. (1449 r.). Perg. $46 \times 31 \mathrm{~cm}$. K. 306. Kol. 2. Pismo wielu rak. Opr. deski w sk. w.spl.

Missale. Calendarium.

1) „Iam prima dies septima a fine..." k. 1.

2) "Exultet" $z$ nutami gregoriańskimi na 5 liniach czarnych k. 136.

3) „Salve sancta Parens, Ave benedicta, mittit ad Virginem” k. 306. Tamże dopisano później 3 oracje.

Kodeks zdefektowany Pergamin kremowy. Wyrwane karty i powycinane miniatury. Inıcjały ozdobne w kolorach: niebieskim, różowym, czerwonym i zlotym. Miniatury na k. ${ }^{104}, 172,192,207,208 \mathrm{v}, 266,273 . \mathrm{Na} \mathrm{k} .158$ dopisek: „Venerabilis dominus Henricus de Radom ${ }^{21}$ archidiaconus Sandomiriensis et canonicus Cracoviensis, nec non Reverendissiml in Christo patris domini Sbignei miseratione divina tituli sanctae Priscae Sanctae Romanae Ecclesiae presbyteri cardinalis et episcopi Cracoviensis vladariusque Cracoviensis defunctus est anno Domini MCCCCXLIX die vero XXIII aprilis et sepultus in ecclesia cathedrali Cracoviensi in capella Beatae Mariae mansionariorum retro summum altare. Liber hic missalis, nolam argenteamque, pixidem argenteam, pro ornatis ornatus pulchrum de Postawiecz auro contextum, humerale cum margaritis, calicem continentem septem marcas argenti totum deaureatum de valore 48 florenorum et ampullas argenteas ad honorem omnipotentis Dei, in laudem

21 Wiśniewski, jw., s. 84. 
B. Marıae Virginis eiusdem Gentrıcıs pro Ecclesia B. Mariae Virginis Sandomiriensi dedit, donavit et legavit” k. 158-159. Na k. 306 napis: „Ex revisione 1707 connotatum" i "Missale donatum ab Henrico archidiacono". Inne dopiski, np. „Orate pro me peccatore".

O p r a wa: deski w skórze białej. Okucıa, guzy i paski. Napis grzbietowy: „Missale, $6 "$ ".

Napis na okkadce o mikrofilmowanıu kodeksu przez Bibl. Nar. w Warszawie 27 III 1963.

Nr 37

(256), (57) Lac. XV w. Papier $16 \times 10 \mathrm{~cm}$. K. 345. Opr. deski w sk. wspl. Sermones.

1) „De Eucharistia. Probet autem seipsum homo... descripsit Paulus in epistola hodierna" k. 1-5.

2) „Dominica Palmarum. Ecce rex tuus venit tibı... vade prius reconciliari fratri tuo" k. 11-16.

3) „De Conceptione Virginis Marıa” I inne kazania maryjne k. 150-182.

4) „In prımitiis novı sacerdotis” k. 199-204.

5) „De Sancto Adalberto" k. 256-261. k. 345 .

6) „Post prandium" - kazanıa w klasztorze, prawdopodobnie żeńskim w PJlsce

Kodeks zdefektowany. Papier w ok. 24 skladkach po 10 do 20 kart. Znak wodny: 2 korony, jedna nad drugą, dolna w zalysie linil serca. Wodne linie pronowe co $3 \mathrm{~cm}$. K. 6-11, 182-186, 212-215, 230-238, 262-267, 317-321, 330-333 nie zapisane. Częste wyrazy polskie.

Oprawa. deska w skórze brązowej, ozdobnej. Slady po klamrach. Napis wycıśnıęty• „Sermones” 1 podobızna krycyfiksu. Naklejka grzbietowa: 256.

\section{$\mathrm{Nr} 38$}

(364) Lac. XV w. Perg. $36 \times 27 \mathrm{~cm}$. K. 287. Kol. 2. Opr. deski w sk. wspl. Porta super epistolas D. Pauli.

1) "Incipit epıstola ad Galatas. Quis dedit Galatae..." k. 1.

2) „Incipit epıstola ad Hebraeos" k. 160.

3) „Explicit postilla super omnes epistolas beati apostoli Pauli. Amen. Incipit postilla super canonicas epistolas auctore Nicolao ordinis fratrum praedicatorum. Incipit prologus in epıstolas canonicas Jacobi" k. 207-208.

- 4) „Explicit postilla super canonicas” k. 283. Alfabetyczny spıs rzeczowy k. 284286.

Kodeks dobrze zachowany. Pergamin cienkı biały. K. 387 czysta. Na końcu napis: „Ex revisione 1707 connotatum"

Op r a wa: deski w skórze białej z wyciśnıętymi linıami. Ślady po okuciach. Na grzbiecie naklejka z napısem: „Super epistolas divı Pauli difficilis”. Inna naklejka $\mathrm{z}$ nr 364 .

Nr 39

(101) Lac. XV w. Perg. $44 \times 34 \mathrm{~cm}$. K. 271. Kol. 2. Pismo wielu rak. Opr. deski w sk. wspl.

Missale.

1) „In Visitatione sanctae Mariae Virginıs. Gaudeamus..." k. 1.

2) „Domınica secunda. Remıniscere miserationum”... k. 3. 
3) „Exultet” - nuty na 5 liniach, k. 66v-69.

4) „In festivitate sancti Lucae. Dilexısti..," k. 151. „Eodem die Walpurgae virgins" k. 166. „Willibaldi, episcopi et confessoris martyris” k. 178.

5) „Incipiunt sequentiae in Nativitate Domini. In Galliciato" k. $260 \mathrm{v}$.

6) „Registrum taxae distributorum (?) Ecclesiae Collegiatae Sanctae Mariae Sandomiriensıs. Praeposito de triginta marcis. Decanus de XV marcis. Scholasticus de VIII marcis". Kanonicy według prebend. Potem ida altarzyści: sanctae Hedwigis - de 2 marcis... S. Laurentii - de 10 marcis" itd.

Kodeks zdefektowany. Pergamin bialy gruby. Po k. 1 i 80 ślady wydarcia. Litery wyraźne, jakby rysowane, wysokości $8 \mathrm{~mm}$. Na początku oficjów litery ozdobne w kolorach: czerwonym, nuebleskim, zlotym i czarnym. Na k. 78 - msza wielkanocna, litera „R" ozdobna, w prostokącie $11 \times 8 \mathrm{~cm}$. Ozdobny słup rozdzielający szpalty. Na początku 1 na końcu napis: „Ex revisione 1707 connotatum”. Numeracja kart XX (2) CCXXV. Reszta ne foliowana.

Oprawa: deskı $12 \mathrm{~mm}$ grube w skórze gładkiej brązowej. Slady po okuciach i klamrach. Na tylnej okladce napis: „Sunt duo qui duo sunt... sunt duo qui duo non sunt”. Na grzbiecie napis: „Missale, 101”.

Nr 40

Lac. 1626 r. Papier $19 \times 15 \mathrm{~cm}$. K. 128. Opr. pólpl. $z X X w^{22}$.

Kronika opatów koprzywnickich.

1) „Praefacio ad fratres. Otiositatem inimicam esse animae asseruit patriarcha et legıslator noster... Quis fuerit fundator Monasterii Coprivnicensis..." k. 1.

2) „Hic vir tantae virtutis erat tanto...”. Do r. 1626. Ostatni opat: Nicolaus Albertus Gniewosz, 34 abbas, commendatarius primus" k. 128.

Papier biały. Napisy o opatach wykonano czerwonym tuszem.

O p r a w a: pólplótno angielskie, zielone.

Kodeks przechowywany w szufladzie.

Nr 41

Pol. 1678 r. Papier $19 \times 15$ cm. S. 13-726. Pismo 2 rak. Opr. deski $w$ sk. $w s p l$.

Zywot S. Matki Teresy od Pana Jezusa... przepisała Jagnieszka od Pana Jezusa... w konwencie Niep. Poczęcia Panny Najwiętszej Lubelskim 23 VIII 1678.

W tymże kodeksie od s. 605 do 610 „O gruncie pokory nazwanym...”. Od s. 613 „Traktat o modlitwie Wiel. Ojca Stefana od św. Teresy" (późniejsza dopiska).

Papier gruby kremowy. Brak początku. Strony nie zapisane: 514-520, 547-548, 611-612. Od s. 528 czystych kart 28.

O p r a w a: deskı w skórze czarnej, ozdobneł, klamry.

Kodeks pochodzl z klasztoru OO. Paulinów w Beszowej. Przechowywany w szafie 1.

$\mathrm{Nr} 42$

(225) Lac. 1678 r. Papier $19 \times 14 \mathrm{~cm}$. K. 148. Opr. wspl.

Metafizyka - skrypt z wykładów.

$22 \mathrm{Na}$ ten kodeks zwrócił uwagę i zapewne polecil go oprawić ks. S. Puławski, proboszcz w Koprzywnicy w latach 1908-1932. W. Wójcik: Ks. Stanistaw Celestyn Pulawski (1866-1937), „Prawo kanon.”, r. 18: 1975, nr 1/2, s. 191. 
1) "Equidem IMetaphysica totius Philosophrae coronis est corona" $25 \mathrm{~V} 1678 \mathrm{k} .1$.

2) „Beatorumque Stanisla1 et Aloysii venerationem”. Na marginesie data: $11 \mathrm{Ja}-$ nuarii... lectio pomerıdiana... 9 Maii k. 148.

Papıer biały gruby, Na margınesach naprsy: C. Bielicki, C. Ballawander, C. Markowski... venıt R. Pater Dore ad rectoratum Lublino... C. Pauli Zawilski... G. Gomolińskı... C. Reuth... C. Robecki... C. Lasocki 1678... G, Turowińskı... P. Trebuchowski... C. Drewnowski... C. Ponińskı. Napis: „Pro Bibliotheca Ecclesiae Collegıtae Sandomrriensı"".

Op r a w a: tektura obciągnięta pergamınem z kancjonału, taśmy. Naklejka grzbietowa: 225. Napis: M.S.

\section{$\mathrm{Nr} 43$}

(31) Pol. 1699 r. Papier $21 \times 17$ cm. S. ok. 500 (liczne wklejki i dodatki). Pismo paru rqk. Opr. wspl.

Stefan Żuchowski X.O.P. Doktor, A.O.P. Sandomiriensıs. Synagoga żydowska starozakonna i teraźniejsza.

1) Odkrycie i obzalowanie błędów, praktyk, okrucieństwa 1 in. kryminałów... z okazji zamordowanego w Sandomrerzu dziecka 1696 i drugiego (dopisek) $1710 \mathrm{r}$. na przestroge stanom koronnym, na ich samych upamiętanıe (Monachomachia contra Iudaeos).

2) Nowy kalendarz świąt rocznych i biegów nıebıeskıch przez Stanısława Waryskiego, Poznań, Drukarnia Akademicka, 1707 s. 16.

Op i a w a. zniszczona. Napis grzbietowy: 31.

\section{$\mathrm{Nr} 44$}

(27) Łac. XVII w. Papier $20 \times 16 \mathrm{~cm}$. K. 130. Opr. wspl.

Varsevicii De optımo statu libertatis libri duo.

1) „Quid causae sit, quod ut plerumque fit non nemo in adversis..." $k .1$.

2) "...sed nec faciem quidem Ignoti hostiae Romani tulerunt, ut nec clamore..." k. 130.

Papıer gruby biały. Napısy: „Ex librıs St. Zuchowski J.U.D. mpp.”. „Pro Bibliotheca Ecclesiae Collegratae Sandomiriensis 1708'.

Oprawa: papier czerwony. Napıs grzbietowy: Varsevicii 27.

\section{$\mathrm{Nr} 45$}

Lac., pol. XVII w. Papier $21 \times 16 \mathrm{~cm}$. K. 164. Pismo paru rak. Opr. $z X X w$.

Philosophia - skrypt szkolny.

1) „Gramatica. Stylus polemicus. Brevis magnı forma favoris” k, 1-6. Logica k. 7-18. Physica k. 19-26. In octo Iibros Physicorum k. 27-127. Metaphysica k. 128150. Doctrina de meteorıs k. 151-153. Distinctionum philosophicarum synopsis k. 154157.

2) „Gramatyka... bez których nıe może być doskonaly czlowiek...” k. 158-164.

Początek znıszczony. Papıer biały. Na k. 131v nazwisko: Luszczeński.

Opraw a: półpłótno angielskıe zielone.

Kodeks pochodzı z biblioteki Cystersów w Koprzywnıcy. 
$\mathrm{Nr} 46$

Lac. XVII/XVIII w. Papier $16 \times 10 \mathrm{~cm}$. K. 118. Opr. wspt.

Breve compendium meditationis pro via purgativa, illuminativa et unitiva ad usum Tyronnum conscriptum.

1) „Introductio. Ùsque adeo sublimis et excelsa est mentalis...” k. 1.

2) „...ut et debitam reverentiam atque adeo cultum exhibere possis" k. 118.

Papier jasno kremowy gruby. 2 karty ostatnie ne liczbowane. Brak końca. .

Oprawa: tektura w pergamıne z tekstem liturgicznym, zatartym. Grzbiet zniszczony.

Kodeks przechowywany w szafie 1 .

\section{$\operatorname{Nr} 47$}

Lac. XVII/XVIII w. Papier $34 \times 21 \mathrm{~cm}$. S. 62. Pismo 2 rqk.

Antiphonarium z nutami na 4 liniach. Od S. Andreae do S. Angelorum Custodum.

Brak końca.

$\mathrm{Nr} 48$

Pol. i lac. 1702 r. Papier $19 \times 16 \mathrm{~cm}$. K. 134. Opr. z XX w.

Katechizm.

1) „Aby kto godnie 1 pożytecznie praystępował do którego sakramentu”. „Introductio cathechistica" k. nlb $1-12$.

2) „Pięć punktów przedniejszych naukı chrześcijańskıe”” k. 1-90. „De usura” kazanie o lichwie k. 91-100. „Examen supra praecepta Decalogi” k. 101-112.

Papier bialy. Napis: 1702 Stradomiae.

O p r a w a: pólpłótno ang. ciemno zielone.

Proweniencja: $\mathrm{z}$ klasztoru w Koprzywnicy.

$\operatorname{Nr} 49$

Lac. i pol. Pocz. XVIII w. Papier $19 \times 15 \mathrm{~cm}$. K. 132. Pismo 2 rak. Opr. wspl.

Syntaxis: gramatyka, stylistyka - podręcznik szkolny.

1) Praefatio ad... Syntaxeos Iuventutem... Lumen primum Polono-Latinis idiomatibus resplendens..." k. $1-2$. k. 29.

2) „Lumen secundum politicis allusionibus in nonnulla Polonae gentis stemmata”

3) „Lumen tertium praxibus carminis Polonıci illustre [ksieni konwentu staiosądeckıego ofiarowany przez Andrzeja Jordana, cześnikowicza krakowskiego 17 II 1714 ]" k, 85. k. 98 .

4) Lumen quartum brevibus et compendiosis epıstolarum praeceptis resplendens"

5) „Lumen quintum praxibus epıstolarum resplendens...” k. 129. Explicit: „swiadkiem będzie szczerej zaś przyjaźnı nieodmiennej W.M.W.M. Pana; którego w przeszłości zalecıwszy sıę lasce..." k. $132 \mathrm{v}$.

Opr aw a: tektura, grzbiet skórzany, nadniszczony. 
$\mathrm{Nr} 50$

Eac. i pol. 1750 r. Papier $17 \times 10 \mathrm{~cm}$. K. 19. Pismo 2 rqk. Opr. wspl.

Liber ad ordinandas missiones tempore Iubilaei Magni a.D. 1750.

1) „Inchoatur missio hoc modo..." k. 1.

2) „Processio et supplicationes ut semper ac in fine: fiant Domine" k. 19. Dodana pieśn: „O Gospodzie uwielbiona...” poprawiona przez K. Czesława Juźwik w r. 1850, Solec.

Op r a w a: tektura w papierze ciemno-brązowym.

\section{$\mathrm{Nr} 51$}

Eac. 1760 r. Papier $16 \times 9 \mathrm{~cm}$. K. 128. Opr. wspl.

Hebdomas sancta sive devotiones per septimanam erga Deum... conscriptae a. 1760 per F.K. - P.P.S. (parochus praepositus Sandomiriensis?).

Dużo różnych litanii (wzmianki o św. Benedykcie i św. Scholastyce). Zbiór używany w klasztorze benedyktyńskim.

1) „Oratio ante quodcumque exercitium dicenda..." k. 1.

2) „,sese suo Regi inclinantis et supplicantis..." k. 116.

Karty czyste do wpisywania dalszych modlitw. Pismo kaligrafowane, w ramkach.

O p r a w a: tektura, grzbiet skórzany, zniszczona.

\section{$\mathrm{Nr} 52$}

Pol. 1770 r. Papier $33 \times 20 \mathrm{~cm}$. S. $121+120+157$. Opr. wspi.

Nauka powszechna na kształt katechizmu czyli krótkie objaśnienie $z$ Pisma św., podania, z historii i artykułów wiary chrześcijańskiej, z sakramentów, modlitw, obrządków i zwyczajów Kościoła, wydrukowana w Paryżu 1728 z rozkazu Karola Joachima Kolberta biskupa de Montpelier... przethumaczona $1770 \mathrm{r}$.

Część I — s. 121, cz. II - s. 120, cz. III - s. 157.

Op rawa: tektura.

\section{Nr 53}

232 Pol. 1776 r. Papier $33 \times 21 \mathrm{~cm}$. S. 134. Opr. $z X X$ w. pótsk.

Andrzej Zamojski. Projekt nowego kodeksu polskiego. Rozdziały: Clerus - elekcja króla. Spis 12 rozdziałów prawa karnego.

Kodeks bez początku 1 końca.

Op r a w a: płótno angielskie.

Proweniencja: z Koprzywnicy.

\section{$\operatorname{Nr} 54$}

Łac. XVIII w. Papier $26 \times 24 \mathrm{~cm}$. K. 37. Opr. sk. wspt.

Antiphonarium.

1) Incipit: „In communi apostolorum extra tempus paschale” $k .1$.

2) Explicit: „In festo SSmi Cordis Jesu”. Brak końca. Nuty na 4 liniach. Napis: Zapowıdzi przedślubne z Sandomierza.

Kodeks nie dokończony.

O p r a w a: skóra brązowa ozdobna, uszkodzona. 


\section{$\mathrm{Nr} 55$}

Lac. XVIII w. Papier $20 \times 16$. K. 44. Opr. $z$ pocz. XIX $w$.

Synodus dioecesana Vladislaviae celebrata a. 1586 a Hieronymo Comite a Rozdrażew episcopo Vladislaviensi et Pomeraniae ${ }^{23}$.

1) „Actum Vladislaviae die 3 sept...” k. 1.

2) „Acta et constitutiones Synodi secundae Dioecesanae Vladislaviae die 22 septembris 1589 per Hieronymum a Rozdrażew episcopum Vladislaviensem..." k. 28.

3) Explicit: ,...paganos in qua ipsi confidunt dextera suae potentiae comprimere et conterere dignetur indicta per suam Il-mam et R-mam D. sunt” $\mathrm{k}$. 44.

Papier jasnoniebieski. Pismo jednej ręki z XVIII w.

O p rawa: tektura. Napis grzbietowy: „Synodus dioecesana Vladislaviensis”.

\section{$\mathrm{Nr} 56$}

(31) Lac. i pol. XVIII w. Papier $16 \times 10 \mathrm{~cm}$. K. 272. Opr. wspl.

Amphiteatrum universi per encyclopediam, id est per omnes scientias artesque naturalem, mythologicam ac historicam eruditionem universi oratori Polono exhibens. Ad M.D.DDGH.

1) „AA - litera; Abundantia” hasła objaśniane k. 1.

2) Explicit: „Caucaseosque refert volucres, furtumque Promaethei...” k. 272.

Część kart nie zapisana. Napis: „Ta książka jest Biblioteki Kapituly Sanđomierskiej, do przeczytanıa dnia 1 sierpnia 1832 r. wzięta, która ma być do Biblioteki na powrót oddana". Na k. 139 wspomniany August III — „święci pamięć”.

O prawa: skóra biđła ozdobna. Napis grzbietowy: „Amphiteatrum Universi”. Naklejka: 31.

\section{$\mathrm{Nr} 57$}

Łac. XVIII/XIX w. Papier $37 \times 21 \mathrm{~cm}$. S. 112. Pismo 2 rqk. Opr. wspt. Antiphonarium.

Festum S. Petri et Pauli - Expectatio BMV. Nuty na 4 liniach. Pieczątka XJS, D.K. (dziekan koprzywnicki?).

Oprawa: tektura.

Proweniencja: może z Koprzywnicy? ${ }^{24}$.

\section{$\mathrm{Nr} 58$}

75 (archiw.) Pol. 1851 r. Papier $32 \times 21$ cm. K. 15. Opr. wspt.

Ks. Krol Gacki ${ }^{25}$. Krótka wiadomość o klasztorze S. Krzyża na Łysej Górze, 1851.

Po k. 15 następne czyste. Napis: „Własność kościoła katedralnego w Sandomierzu”.

Oprawa: broszura.

23 Pelny tekst synodów z 1586 i 1589 r. pt. Statuta synodalia dioecesis Wladislaviensis et Pomeraniae, wyd. Z. Chodyński, Varsovia 1890, s. 95-139.

24 Przypuszczalnie przekazany po kasacie klasztoru w Koprzywnicy w $1818 \mathrm{r}$.

25 Por. Polski Słownik Biograficzny, t. VII, s. 196-197. 
$\mathrm{Nr} 59$

Pol. XIX w. Papier $20 \times 17 \mathrm{~cm}$. K. 900. Opr. wspl.

Historia prawa polskiego. Prawo prywatne. Streszczenia i odnośniki do Volumina Legum.

Brak początku i końca.

Opraw a: tektura. Napis na naklejce grzbietowej nieczytelny.

$\mathrm{Nr} 60$

151 (archiw.). Pol. Druga pol. XIX w. Papier $31 \times 19 \mathrm{~cm}$. K. 36. Opr. $w s p t$.

Ks. Justyn Łada ${ }^{26}$. Mszalik unicki św. Jana Chryzostoma liturgię zawierający $\mathrm{z}$ tłumaczeniem polskim w rękopisie. Tekst drukowany w języku starosłowiańskim.

O p r a w a: tektura, grzbiet płócienny.

Proweniencja: dar córkı Łady, Radom 1906.

\section{INDEKS IMION I NAZW GEOGRAFICZNYCH \\ (Cyfry oznaczaja numery pozycji)}

Adalbertus, sanctus 4,37

Agalbertunus Tagarnopolitanensis 7

Alojzy (Gonzaga), b1. 42

Ambrosius, frater 30

Anastazja, św 2

Andreas de Zarnów 12

Anzelm, św. 27

Astesanus, v. Franciscus de Abbate Ast.

August II, król 56

Augustyn, św. 27

Ballawander C. (?) 42

Baysionensıs, v. Guido

Beda, Venerabilis 1, 27

Benedylkt, sw 51

Beszowa, paulinı 41

Bidziny, v. Stanislaus de

Bielickı C. (?) 42

Byeski (?) 32

Cotrıcus (?), praepositus 23

Derdek (?) 32

Dore o. (?) 42

Drewnowski C. (?) 42

Duczek (?) 32

Eleemosynarius, v. Joannes Ellemos.

Fabruus Martinus (?) 21

Franciscus de Abbate Astensis 8

Gackı Karol, ks. 58

Gniewosz Nicolaus Adalbertus 40

Gomolińskı G. (?) 42

Goszcz, v. Stanislaus de Opatów

Gotfricus, decanus Herbipol. 23

Gottifredus, mgr, can. Crac. 24

Gregornus, officialis Sandom. 12
Gregorius IX, pap. 18

Grzegorz X, pap. 23

Grzegorz Wielk1 3, 27

Guıdo de Baysı 17

Henrıcus de Radom, archidiac. 36

Herbipolensıs, v Gotfridus

Hieronım, św 1, 3, 27-30

Hieronymus a Rozdrazew, bp 55

Innocenty IV, pap. 23

Jacobus, apostolus Alphe 24

Jacobus de Voragine 21, 33

Jakub Mirkowski (?) 32

Jadwiga, św. 4

Jagnıeszka od P Jezusa 41

Jan Chryzostom, św. 27

Jan Ewangelista 1

Jezowsk1 Aleksander 29

Joannes a vicecustodia (?) 32

Joannes Eleemosynarius 14

Joannes, dictus Pfuer, mgr, 21

Joannes, frater, lector 9

Jordan Andrzej 49

Juźwik Czesław 50

Katarzyna, męcz., św. 2

Kaweczka, v. Stanislaus de Vidava

Kazimierz Wielk 1

Kolbert Karol Joachim, bp 52

Koprzywnica $40,45,48,53,57$

Lasocki C. (?) 42

Leon Wielkı 27

Listowski (?) 4

Lublin $41-42$

Ludwik, król Francji 1

20 Ksıądz greckokatolickı, pracował $w$ banku radomskım i potajemnıe odprawial mszę św. w swolm obrządku. Notatka pisana ręką ks. J. Wiśnıewskıego. 
Lucas, evangelista, Syrus 1, 39

Lyra Nicolaus de, v. Nicolaus

Lada Justyn, ks. 60

Lysa Góra, v Swlęty Krzyz

Markowski C. (?) 42

Martinus, v. Fabrius

Martınus Sczebel (?) 32

Monaldus, OFM, kanonista 12

Nicolaus (?) 16

Nicolaus de Lyra 3, 22, 25-26, 34, 39 (?)

Nicolaus, vicedecanus vicarıorum Sandomiriensium 25

Oleśnıckl; v. Sbigneus

Opal, ımıę 4

Opatów, v. Stanıslaus de

Petrus, legat librum 9

Petrus de Posnania 33

Petrus de Tarantasia $15-16$

Petrus Mirowsk de Cracovia 36

Petrus de Voragine 16

Peyser, Pyser Nicolaus, mgr 5, 35

Pfuerı, v Joannes mgr

Ponınskı C. (?) 42

Poznań, v. Petrus de

Quodvultdeus, Centuriensis ep. 18

Rabanus Maurus 1

Radom 60

Radom, v. Henricus de

Raymundus de Pennafort 5, 9, 35

Reuth C. (?) 42

Robeckı C. (?) 42

Rokoszny Józef, kks. 24

Rozdrazewski, v. Hieronymus a Rozdrazew
Sandomiriensis Ecclesia 5, 10, 13, 21, 33, $35-36,39,42,43-44,54,56,58$

Sbıgneus card. Oleśnick 36

Scholastyka, św 51

Sczebel, v. Martinus

Sczuka, can. Sendigal. (?) 32

Sendigal., v. Sczuka

Solec 50

Stanislaus, cmetho de Bidziny 25

Stanıslaus (Kostka), beatus 42

Stanıslaus de Opatów, dictus Goszcz 8

Stanıslaus Kaweczka de Vidava 14

Stanısław, bp. sw 4

Stary Sącz 49

Stefan od św Teresy 41

Swlęty Krzyż, Łysa Góra 58

Tagarnopolitanensis, v. Agalbertunus

Tarantasia, v Petrus de

Teresa od P Jezusa, św. 41

Thomas de Aquino 19-20

Trebuchowski P. (?) 42

Turowiński P. (?) 42

Varsevicius 44

Vidava, v. Stanıslaus de

Vladislavia 55

Voragine, $v$ Jacobus, v. Petrus de

Waryski Stanısław 43

Wieslołowski Miroslaw 29

Zamojskı Andrzej 53

Zawilskı Paulus C. (?) 42

Zarnów, v Andreas de

Zuchowski Stefan 43. 